\title{
Globalization, Democracy and State Autonomy: An Empirical Exploration of the Domestic Consequences of Globalization
}

\author{
Jaekwon Suh
}

In this article, I explore how domestic political institutions mediate the relationship between globalization and state autonomy. One dimension of democracy - the capacity to manage conflicts - is a crucial factor in maintaining the state's autonomy from international economic shocks. The article provides statistical evidence showing that globalization's constraint on state autonomy disappears once the degree of democratic development is taken into account. This finding sheds light on why both developing and advanced industrial countries need to keep improving state governance to remain politically and economically viable in an increasingly volatile international political economic landscape.

Key Words: democracy, globalization, state autonomy

S ince the autumn of 2009, businesspeople, financial experts and high-profile $\boldsymbol{N}$ policymakers have paid a growing attention to developments in European Union member countries such as Greece, Italy, Spain, etc. Indeed, the crises of public finance in the European Union have heightened concerns both within and without the region (Sgherri and Zoli 2009; Featherstone 2011). Many of these concerned observers have pointed to globalization as an important source of these crises. This claim has its roots in arguments involving the constraints that globalization can impose on state autonomy. In an international economy of fixed exchange rates and freedom of movement of capital, for instance, the state loses the ability to control of its economy through macroeconomic policy. Economists attribute this loss of control to a "trilemma" or "irreconcilable trinity" (Gilpin

*Jaekwon Suh (scholar.suh@gmail.com) teaches comparative politics, political economy and methodology in the department of political science at Pusan National University. He previously was an assistant professor in the department of political science at Truman State University, Missouri, USA. His research interests include economic effects of constitution, political determinants of corporate governance, government regulations in labor and financial markets, economic inequality and distributive politics in the era of globalization, etc. His articles appear in Public Choice, Korea Observer, Korean Political Science Review, etc.

I wish to thank the three anonymous reviewers for helpful comments, and extend special thanks to Eric Zusman for his help in editing. Mistakes of fact and interpretation are mine alone. This study was supported by the Fund for Humanities \& Social Studies at Pusan National University 2013. 
2000, 122-123). States may want stable exchange rates to reduce economic uncertainty and also want discretionary monetary policy to promote economic growth and steer their economies between recession and inflation. In addition, they may want freedom of capital movements to facilitate the conduct of trade, foreign investment, and other international business activities. Unfortunately, an international monetary system can accommodate at most two, but not all three, of these desires. ${ }^{1}$

Carrying this claim forward to the domestic consequences of globalization, most scholars agree that globalization gives rise to income volatility and amplifies income inequality; as for other consequences there is less of a consensus. In general, scholars view the consequences of globalization in three contracting ways. The first is a market-deterministic view (Andrews 1994; Cerny 1994; Gill and Law 1989; McKenzie and Lee 1991; Omae 1995; Strange 1986). This view holds that the aforementioned income volatility is transient and the ultimate outcome of globalization distributes benefits to the rich and poor evenly. The second is a state-deterministic view (Cohen 1995, 1998; Evans 1997; Helleiner 1994; Hinnfors and Pierre 1998). This view argues that globalization is meaningless without the nation states, which still control the speed and degree of economic integration. Income volatility continually reoccurs and the benefits of globalization are distributed between the rich and poor unevenly. It is the state that controls unruly market forces even in the era of globalization. Both the market-deterministic and the state deterministic views have a normative slant, making it difficult to derive positive policy implications from their prescriptions.

A third view on the consequences of globalization is known as domestic institutional dynamism (Garrett 1995, 1998a, 1998b; Goodman and Pauly 1993; Keohane and Milner 1996; Hirst and Thompson 1999; Mishra 1996). This view suggests that both optimistic and pessimistic consequences of globalization depend on domestic institutions. Policymaking preferences are not fixed but vary case by case according to the kinds and strength of external stimuli and domestic institution. Therefore, even the same kind of external shock may well bring about a variety of policy outcomes depending on each country's domestic politics. Well-

\footnotetext{
${ }^{1}$ Gilpin further takes an example of how globalization constrains states' policy autonomy. "A system of fixed exchange rates such as the Bretton Woods System, with some latitude for independent macroeconomic policies, is incompatible with freedom of capital movement because capital flows could undermine both fixed exchange rates and independent macroeconomic policies. A system with fixed exchange rates and independent macroeconomic policies promotes economic stability and enables a government to deal simultaneously with domestic unemployment. However, such a system sacrifices freedom of capital movement, one of the most important goals of international capitalism" (2000, 123).
} 
designed and developed domestic institutions can solve the problems that globalization produces.

In this article I explore how domestic institutions mediate the relationship between globalization and state autonomy. ${ }^{2}$ This research finds that one dimension of democracy - domestic institution for conflict management-is one of the most crucial factors in maintaining the state's autonomy against external shocks that globalization brings about. Statistical evidence shows that globalization's constraint on state autonomy disappears once the degree of conflict management institutional development is taken into account. This finding sheds light on why not only developing but also advanced industrial countries like the EU members in financial crisis should never stop developing their political systems to survive ever-increasing external shocks in the era of globalization.

The next section introduces three previous studies pertaining to important themes in public finance. The third section outlines theoretical considerations of how domestic institutions affect the supply and demand of government services. Several testable hypotheses are put forth based on this logic. In section four, a series of multiple regressions are carried out to test these hypotheses. The final section summarizes the results, discusses the political implications, and points to further areas of research.

\section{THE CAUSAL NEXUS BETWEEN ECONOMIC OPENNESS AND PUBLIC FINANCE}

In the 1970s, studies on public finance were motivated by concerns about the growth of the public economy. This motivation came from both academia and the private sector because a rapidly growing rate of public spending was believed to have a harmful effect on economic development. Consequently, many researchers became interested in which factors gave rise to this expansion in public expenditures. Cameron (1978) was one of the first to report this trend, finding that trade openness is the single most important variable explaining the growth of the public economy. In the years that followed, several economists

\footnotetext{
${ }^{2}$ Presumably, the statist-versus-institutionalist debate in the late 1990's can give us some impression that the term, state autonomy is not institutionalist but statist, because the institutionalist accused of the statist of being too centered on state autonomy-in other words, too disregarding the social actor. However, the developmental statism, which is involved in the debate, is itself institutionalist. Therefore, the term of state autonomy assumes states not against but interdependent or connected to society. As for the statist perspectives, refer to Wade (1990) and Onis (1991). As for the institutionalist, refer to Evans (1995) and Weiss $(1995,1998)$.
} 
and political scientists elaborated upon his findings with different research focuses such as emerging "tax states"-defined in terms of extractive capacity of general government-and the scope of government (Schmidt 1983; OECD 1985).

In the 1990s, Rodrik (1996) shifted the research program to look specifically at the impacts of globalization on the scope of government. Rodrik argues that trade openness makes countries vulnerable to external shocks. Such vulnerability results in income volatility or aggravated inequality, which usually leads to domestic conflicts as well as increasing demand for public services. To put it another way, economic integration exposes national economies to the turbulences in the world economy, generating more uncertainty and volatility in the domestic economy (Sheve and Slaughter 2004). Faced with greater insecurity, the state would be obliged to provide more social protection and insurance. As a result, the more open the economy the bigger the government. I take Rodrik's argument as a benchmark and call it "compensation hypothesis."

Although Rodrik's argument follows logically, it is premised on the assumption that all governments are institutionally alike and constituents' demands on public services are automatically translated into the government's supply of the demanded services. The problem with this assumption is that it fails to take into account the fact that states are autonomous to varying degrees. When facing external shocks, different institutional arrangements in states react differently to popular demands. Rodrik's dependent variable, the scope of government (operationalized as the supply of public services) might vary depending upon how different institutional arrangements react to external shocks. To compensate for the omission of institutions, in this article I turn to Garrett.

In sharp contrast to Rodrik's uniform treatment of institutions, Garrett (1998b) developed a model that allowed for moderate domestic institutional variation. He argues that institutional coherency between government's ideological orientation and the degree of unionization in the labor market help governments maintain high levels of macroeconomic performance. Garrett's explanation can be understood in terms of the supply and demand of government services as follows: Governments with a social democratic partisan orientation tend to intervene in the private sector with many public provisions to help cope with collective bargain demands from nationwide labor unions; in contrast, governments with a liberal partisan orientation tend to be lasses-faire and supply lower levels of public provisions, effectively letting labor-union-management relationship develop naturally (Hall and Soskice 2001). Therefore, he implies coherent domestic institutions are good at coordinating the supply and the demand of public provisions needed to offset the negative effect of globalization on domestic politics. Hence a 
national economy possessing these institutional attributes can sustain economic growth, price stability, and employment, despite globally induced external shocks.

Although Garrett's argument does an exceptional job of capturing the effect of institutions in advanced democracies, it is not widely applicable to developing countries. Garrett only examines, at most, 14 advanced industrial countries. To include more countries, Garrett's explanatory variable-institutions - and his dependent variables must be slightly modified. First, the institutional coherency standard may well lose its political meaning because in developing countries whether a country is democratic or authoritarian takes precedence over right-versus-left partisan politics. Therefore, in an effort to explore the effects of institutions across a larger number of countries, one must turn to regime type as a mediating variable.

Another important modification to the Garrett model involves the dependent variable, i.e., a country's macroeconomic performance. The implication that good macroeconomic performances are indicators for the goodness of state governance is not always valid in developing or authoritarian countries. Similarly, macroeconomic indexes do not fully embody what governments have done to counter external shocks because policies taken are not always consistent with outcomes achieved. For example, the fact that the inflation rate is low does not always mean that the government has carried out an anti-inflationary policy. Therefore, we need to specify a variable that better captures the level of government activities closely related with social protection and insurance. To compensate for the limited applicability of Garrett's macroeconomic performance to a larger sample size, in the article I return to Rodrik's government consumption as a dependent variable - which I discuss later.

The next section explains how a government generally responds to demand for public services and how democracy influences the supply and demand of public services. In the section I also build several testable hypotheses from this reasoning.

\section{HOW DOES DEMOCRACY AFFECT GOVERNMENT PROVISION OF PUBLIC SERVICES?}

\section{THE ROLE OF GOVERNMENT: SUPPLIER RESPONDING TO DEMAND OF PUBLIC SERVICES}

Countries pursuing economic development dictated solely by free market principles run the risk of confronting market failure. The risk of market failure is one 
of the chief reasons governments intervene in the market. A related problem, as illustrated by Lehner and Widmaier (1983) is social market failure:

\begin{abstract}
Markets possess an inherent tendency to fail socially. [....] The basic social problem of the market working within a given distribution of income and wealth is that it often provides goods and services in quantities and at prices that are not consistent with the needs and preferences of certain parts of population. This is likely to produce considerable dissatisfaction with market allocation. Dissatisfaction will, in turn, under certain conditions result in pressure for government intervention. While this problem may occur in simple as well as in differentiated societies, it is more strongly accentuated and increased by societal differentiation. $(1983,242)$
\end{abstract}

In such cases governments can act as mediators resolving conflicts between different dissatisfied groups. However, while government interventions resolve dissatisfaction at the social aggregate level, the provision of services does not always meet demands at the individual level. Because of the paradox between aggregate and individual demands the supply of public services is frequently suboptimalthat is, short of demand. Most states confront the political challenge to balance supply and demand of public services.

To illustrate via an example, suppose a government meets citizens' demands with two kinds of resources. One resource is financial and the other is regulatory (Musgrave 1978). Although a government plays the role of supplier of both types of resources, it relies first and foremost on the financial resources because the primary demand is for financial resources and regulatory resources are de facto less efficient (Tanzi 2000). The financial supply may increase enough to cover demand as long as government secures sufficient revenue. However, tax-resistance and budget deficits frequently inhibit the ability of governments to collect sufficient revenue.

The remaining option for government is regulatory activities. Through regulations the government externalizes a considerable part of its own costs, making the beneficiaries of public services absorb the cost of the services. But regulatory activities also impose political burdens on the government. To make matters worse, they can harm a government's legitimacy because they often lead to rentseeking and other forms of predatory behavior.

If the above described scenario is true, how is it that all governments do not constantly face a threat to their legitimacy? The answer is domestic institutions. Institutions provide education, communications, deliberation, accountability, and the articulation and aggregation of interests, shoring up the legitimacy of the 
state by reducing the likelihood of conflict. Institutions mediate conflict at both the individual and group level. At the individual level, highly developed institutions curtail overly excessive demands on government. Institutions reduce excessive demands by repositioning that demand back on the people through, for instance, higher level of taxation.

At the group level, institutions also prevent interest groups from laying excessive claims on government. To cite one of their many functions, they act as a buffer zone between public demands on government and government supply of public services. This role is particularly important when governments face shortages as often happens after an external shock. To reiterate the key point, institutions moderate the level of conflict between individuals, groups and the government.

Since democracy is a comprehensive institutional variable that entails conflict management functions and can be operationalized numerically, in this article I show how democracy affects the supply and the demand of government services.

\section{DEMOCRACY AND GOVERNMENT PROVISION OF PUBLIC SERVICES}

The commonly accepted concern is that globalization constrains state autonomy by placing excessive demands on the state. However, unlike the manageable demands that come from domestic social market failure, these demands originate from irreconcilable problems such as the aforementioned "trilemma" and from other difficulties controlling influences such as "speculation in exchange markets." In these cases, states are hamstrung due to the suddenness of change. As a result, globalization can aggravate already existing domestic social market failure. 3 Yet all is not without hope. The sharp pains caused by external shocks can be remedied by democracy - or more specifically democratic institutions. Formally, it has been shown that democracy mitigates the intensity of social market failure for the following three reasons (Dixit 2003; Rodrik 1999).

First, democracy can generate compromise by altering preferences. As individuals meet and deliberate, they come to understand each other's points of view, develop empathy, recognize the value of moderation, internalize common inter-

\footnotetext{
${ }^{3}$ South Korea during the Asian financial crisis in 1997-98 provides a good example. At the expense of taking the austerity program the International Monetary Fund (IMF) imposed, South Korea took a bailout loan. South Korea's government was helpless in terms of fiscal and financial policy measures until 2001, when it redeemed the bailout loan.
} 
ests, and de-emphasize narrow self-interests. Second, democracy induces cooperative behavior by helping to form a consensus around constitutional rules such as separation of powers, specific minority protection clauses, and the rule of law. Third, democracy can result in more frequent cooperation even without explicit constitutional rules because repeated interaction among contending interest groups leads to greater cooperation. For these reasons, I modify Rodrik's "compensation hypothesis" as follows:

H1: Even though globalization gives rise to income volatility and thus increases demand for government services, democracy can lower the level of demand for government services by helping people to be self-limiting in demanding public services.

Next, I examine how democracy affects the supply of government activities. By and large, two explanations can shed light on how democracy increases the state's supply of public services. One pertains to democratic government's extractive capacity and the other pertains to a democratic government's tendency to appeal to the median voters.

Levi's discussion of a democratic government's extractive capacity illustrates why democracies supply more services than any other regime types (1988). "Quasi-voluntary compliance" minimizes the compliance costs associated with taxes and, as a result, enhances the state's capacity to collect tax. In order for this compliance function to work, two conditions must be met: 1) people hold the perception that there is bargain between the government and citizens in which the government provides positively valued public goods in exchange for payment of taxes; 2) the existence of assurances that the government and other taxpayers will keep their sides of the bargain (Cheibub 1998). Democracy can foster these conditions by means of periodic elections, freedom of information and a deliberative law making body. These institutional arrangements offer the government more resources, which it can use to supply public services.

Another relevant rationale for why democratic governments supply more public services than other types of regime involves incentives to return revenue to certain part of the population. Democratic governments have an incentive to supply services to their constituents because they are by definition accountable (Keefer 2007). For instance, democracies consider most heavily preference of median voters, which are typically composed of labor and less wealthy segments of the population. ${ }^{4}$ This working and poor majority tends to prefer immediate govern-

\footnotetext{
${ }^{4}$ Some may argue that this is the case only for countries with majoritarian electoral systems. But proportional counterpart, the other family of electoral systems, makes countries responsible for a wider range of constituents than majoritarian counterpart as far as the countries are democratic.
} 
ment consumption because the discount rate for future consumption is said to be negatively correlated with income level. This fact forces democratic governments to provide those services sooner rather than later. ${ }^{5}$ This micro-social argument illustrates how democracies appeal to median voters and thereby make efforts in circumventing social market failure. Integrating this micro-social argument and the quasi-voluntary compliance argument as mentioned above, I hypothesize the following:

H2: Democracy induces the state to supply more public services.

In this article I use government consumption to measure the supply of public services for empirical analyses. Yet aggregate consumption figures can be deceiving. There are many ways of raising financial resources for consumption and some of these methods can be fiscally irresponsible. For instance, governments can print money, borrow money, or overspend themselves into a deep budget deficit or high inflation rate. Although macroeconomic effects of these measures are not equal and not always harmful, I treat them as damaging the fiscal health of the country in question. To check the soundness of government fiscal activities, I test two additional hypotheses that purposefully distinguish between healthy and deleterious resource consumption. These hypotheses assume that globalization increases the demands on government services, governments must meet these heightened demands (state autonomy is constrained), and democracies have a higher extractive capacity.

H3: Globalization impairs fiscal health

H4: Democracy helps government maintain fiscal health.

\section{EMPERICAL ANALYSIS}

\section{VARIABLE SELECTION}

In this article I use OLS multiple regression analysis to test the hypotheses discussed in the previous section. This subsection explains how to measure or take proxies of the main variables such as the supply and the demand of government

\footnotetext{
${ }^{5}$ Schweinitz points out two other causes of the constant demand of the majority for immediate government consumption. First, in the process of economic development (he seems to assume that economic development follows democracy), demands will increase much faster than the economy's capacity to satisfy them. The disparity will be experienced by the majority of the population as a deficit in consumption, thus providing an extra incentive for demanding increased current consumption. Second, competition forces labor and party leaders to step up demands for immediate consumption, no matter how unwilling they are to do so. Karl De Schweinitz, Industrialization and Democracy (New York: Free Press, 1964). Recited from Cheibub (1998, 351).
} 
activities, democracy, and globalization.

First, I take the ratio of government consumption - a part of the total outlay of government expenditure - to GDP as the indicator of the supply of government activities rather than the ratio of revenue to GDP. It is customary for economists and political scientists to assess the role of government in the economy by measuring the ratio of tax revenue or government spending to GDP (Tanzi 2000). If so, why take government consumption among many categories of government expenditure as the proxy of supply?

There are two primary reasons. The first concerns the size of the dataset. Because in this article I attempt to explain a relationship between globalization and state autonomy over developed and developing countries, it is necessary to define supply in the most general way possible. In less developed countries, where a western-style advanced welfare state is not present, only government consumption can serve a welfare function by, for instance, stimulating demand in domestic market. For these reasons, I use Heston-Summer measures of government consumption, which is applicable to a large- $\mathrm{N}$ data because it is adjusted for purchasing-power differences across countries. The second justification for using government consumption as a proxy of government supply involves replicating the basic form of Rodrik's regression model. ${ }^{6}$ With this basic form intact, I can extend his model by including an institutional variable to test the four hypotheses.

I also use the Gini coefficient as a proxy of the demand for government service assuming that Gini coefficient is a measure of inequality and approximates unavoidable social dissatisfaction - that is, social market failure. Critics may argue that more visible indicators of social dissatisfaction should be used such as the number of demonstration due to the lack of public service and the number of labor strikes due to dissatisfaction of welfare and wage levels. However, these measures are not available for a large number of countries and, in particular, finer grained measures of dissatisfaction (e.g., labor strikes) are susceptible to multiple interpretations depending on the context.

The next variable, globalization, is measured with trade openness. Some may suggest that international finance tends to receive greater attention than international trade these days. But this article prefers international trade for a proxy of globalization because the effect of international finance on the coalition and dissolution of domestic interests and preferences - ultimately domestic conflict-

\footnotetext{
${ }^{6}$ In this article I use the same data used by Rodrik (1996), and am indebted to him for sharing the dataset.
} 
has not been explored as much as that of international trade. Moreover, from a practical point of view, international financial data are too limited in supply to comprehend less developed countries.

The final variable, democracy, is measured using Polity IIId. The Polity IIId index has four strengths. First, the index is the most widely employed regime type variable (McLaughlin et al. 1998). Second, the project coding Polity IIId has established a high level of credibility because it has been ongoing since the Polity study was initiated by Ted Gurr in the late 1960s. Third, Polity IIId codes regime type indicators-democracy, autocracy and centralization of state power-with attention to sharp detail, specifying the month and day of changes in political regime explicitly. Fourth, the index provides gradations of democracy, distinguishing between advanced western countries that would otherwise be coded the same if a dichotomous variable was used.

This fourth strength is worth highlighting. Because Polity IIId is a graded democracy index it captures autocratic characteristics that exist in democracies and democratic characteristics that exist in autocracies. To illustrate, take the difference between social democracies and liberal democracies. Polity IIId can differentiate between the two democratic types, accounting for the degree of government regulation in the latter and market freedom in the former (Jaggers and Gurr 1995). In sum, we can get more information of how democratic each country is from Polity IIId and this information is essential for a large $\mathrm{N}$ case study.

The algorithm for calculating the democracy variable (Polity3) with Polity IIId is as follows. In this article I sum each score on a scale of 0 to 10 on two indices, an "institutionalized democracy" (ID) index and an "institutionalized autocracy" (IA) index. Both indices run from the end of World War II (1945) until 1990. I then subtract the sum of IA index from the ID index and divide the result by the total number of years for which there is available data.

To confirm the algorithm's validity, I compare Polity3 with other democracy variables (see Table 1). Two other indicators and two subsets of the calculated variable based on Polity IIId are used. Demo70s from Freedom House and Demo46, coded with dummy values during 46 years, are the other sources. Because the 1970 s were marked by political and economic changes like the breakdown of the Bretton Woods system, the structural transition of international relations from bipolar to multi-polar system, two oil shocks, and rising NICs (newly industrialized countries) like Singapore, South Korea, Taiwan, etc., I also divide the data into a pre-1980 subset ( $\mathrm{Pol} 34680$ ) and a post-1980 subset (Pol38094). The same algorithm is applied to these subsets. 
Table 1. Summary Statistic of the Indices of Democracy*

\begin{tabular}{|c|c|c|c|c|c|c|c|c|}
\hline & \multicolumn{5}{|c|}{ Correlation } & \multirow{2}{*}{ Mean } & \multirow{2}{*}{ Median } & \multirow{2}{*}{ reference } \\
\hline & Demo70s & Polity3 & $\operatorname{Pol}_{4680}$ & Pol3 8094 & Demo46 & & & \\
\hline Demo70s & 1 & & & & $(\mathrm{~N}=83)$ & 0.49 & 0.39 & $\begin{array}{l}\text { Mean : Bangladesh } \\
\text { Median: Thai, Nigeria }\end{array}$ \\
\hline Polity3 & 0.84 & 1 & & & & 0.48 & 0.38 & $\begin{array}{l}\text { Mean : Guatemala, Honduras } \\
\text { Median: Nigeria, Myanmar }\end{array}$ \\
\hline $\operatorname{Pol}_{4680}$ & 0.823 & 0.984 & 1 & & & 0.47 & 0.33 & $\begin{array}{l}\text { Mean : Guatemala, Brazil } \\
\text { Median: Thai, Uganda }\end{array}$ \\
\hline Pol3 $_{8094}$ & 0.851 & 0.928 & 0.848 & 1 & & 0.52 & 0.43 & $\begin{array}{c}\text { Mean : Nepal, Senegal, } \\
\text { Guatemala, Nicaragua } \\
\text { Median: Panama, Hungary }\end{array}$ \\
\hline Demo46 & 0.74 & 0.72 & 0.735 & 0.62 & 1 & 0.22 & 0 & Dummy variable \\
\hline
\end{tabular}

* Here, Polity3, Pol3 ${ }_{4680}$, and $\mathrm{Pol}_{8094}$ are rescaled values from 0 to 1 for convenient comparisons.

Table 1 displays summary statistics and correlations between different democracy measures. Note that Polity3, $\mathrm{Pol}_{34680}$, and $\mathrm{Pol}_{38094}$ are rescaled values from $\mathrm{o}$ to 1 for convenient comparisons. The different measures are highly correlated and the values of their means and medians are similar. Of all the measures, Demo46, the dummy variable, has the lowest level of correlation with the other measures and a mean and median that is most distinct from the other graded measures. This subtle difference implies that we lose information by dichotomizing but may gain interpretational convenience.

As for the other geographic, demographic and socioeconomic control variables, I use the same set of variables found in the typical growth regression models and the government expenditure regression models (Barro 1991; Heller and Diamond 1990; Tanzi and Schuknecht 1995). (See Appendix 1 for theoretical rationale and the source of these variables.)

\section{STATISTICAL EVIDENCE}

\section{Summary Statistics on Primary Explanatory Variables}

Although this article does not aim to analyze time series data, it needs to find any variation over time in the two main explanatory variables-globalization and democracy. Assuming that there were significant qualitative changes in the world in the 1970 , I compare a period from 1946 to 1979 with a period from 1980 to 1992 for democracy variation over time and observe any trends with three averaged openness indexes -1970s, 1980 s and 1990-92 -for globalization variation over time.

This research finds that the world became more economically integrated and democratic in the 1980 s and the early 1990 s compared with the previous period of 1946-1979. Figure 1 evinces these facts visually. Both mean and median values of democracy indices increase with the same variance. Changes in the degree of democracy are summarized according to regional categories as follows (see 
Figure 1. Periodic Comparisons of Democracy and Globalization

Democracy

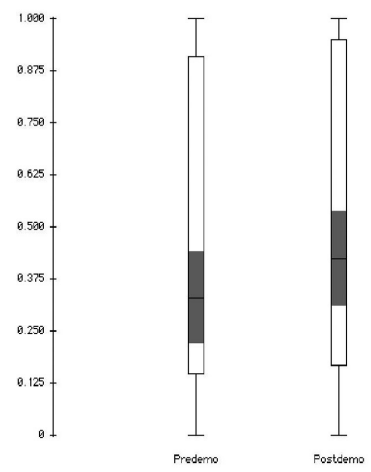

Globalization

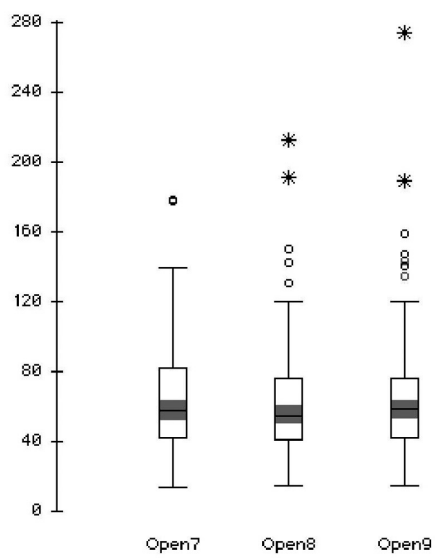

\begin{tabular}{cccccc}
\hline Mean & .47 & .52 & 67.8 & 68.7 & 70.1 \\
\hline Median & .33 & .43 & 61 & 57 & 59.6 \\
\hline $\begin{array}{c}\text { Standard } \\
\text { Deviation }\end{array}$ & .36 & .36 & 35.8 & 37 & 47.9 \\
\hline $\mathbf{N}$ & 118 & 120 & 126 & 131 & 107 \\
\hline
\end{tabular}

Appendix 2). Latin American countries are shown to have accomplished democratic development. Former socialist countries are shown to have improved their political situations in terms of liberties and civil rights. OECD countries are keeping the same level or have upgraded the level of democracy with the exception of Turkey. On the contrary, the overall level of democracy has fallen in Sub-Saharan African countries.

Meanwhile, the means and medians of globalization in the three periods do not show a consistent trend. While the mean values say that globalization progresses, the median values tell that globalization regresses and progresses. One caveat for reading the statistics is that the mean and the standard deviation are not robust to outliers. For instance, the highest level of openness is found in Hong Kong whose openness has climbed from $179 \%$ in the 1970 s to $274 \%$ in the early 1990s. Presumably, outliers as Hong Kong and Luxemburg seem to continue to push up the mean.

The lack of robustness of the means notwithstanding, the medians of openness, a robust measure to outliers, show an upward trend from the 1980 s to the early 
1990s. Why do the medians of globalization drop from 1970 s to 1980 s and then increase from the 1980 s to the early 1990s? Explanations are possible with two oil shocks in the 1970s and the rise of the Asian Tigers in the 1980s. The skyrocketing oil price must have exaggerated the trade volume in the 1970s. Due to technological innovations for higher energy efficiency, industrial countries acclimated themselves to the high oil price. Consequently, the exaggeration in trade volume was eliminated in the 1980 s. Meanwhile, the rise of the Asian trade states brought back global economic integration but created larger variation to the distribution of the degree of openness in the early 1990s.

Even though such basic statistics leave room for further debate on the existence of globalization, they do not reject the existence of globalization totally. Next, I return to cross-sectional analyses of the effect of globalization on state autonomy when the degree of democracy is taken into account as an intervening variable.

\section{Regression Analyses}

In this article I adopt Garrett's approach to test the hypotheses with multiple regression analyses (1998b). He builds two models: a closed model and an open model. After benchmarking the closed model, he puts external variables into the benchmarked model and observes any changes in the regression results.

As hypothesized in the previous section, does democracy moderate the demand for government activities? In this article I use the bivariate regression models and the simplest multivariate regression models based on the reasoning about institutional effect on the demand of government activities. Both graded (Polity3) and dichotomous (Demo46) democracy indices are used for checking any statistical anomalies and for convenience in interpreting coefficients.

Table 2 shows that democracy lowers the level of demand for government services. Column (1) shows that one point increase in democracy makes the level of inequality decrease by .85 . Column (2) shows that there is a 10.6 points gap in the Gini coefficient between non-democratic and democratic countries.7 Both democracy variables explain the demand side of government services with conventionally accepted statistical significances. However, the explanatory power of the regression models is limited on the adjusted R-squared (6.8\% and $2.1 \%){ }^{8}$

\footnotetext{
${ }^{7}$ For assessing a change in the degree of inequality as the degree of democracy increases, specific comparisons will be more helpful. According to regression (1), for instance, the regression coefficient of Polity3 variable can be understood as a distance between Bolivia and the United States located in a coordinate with democracy (x-axis) and Gini index (y-axis).

${ }^{8}$ I diagnose the residual scatterplot, which shows some pattern according to the regime types and regional difference although it does not show heteroskedasticity. The past socialist countries, social democratic countries and Asian developmental states denote relatively lower inequality while coun-
} 
Table 2. Regression Results: Demand Side

\begin{tabular}{|c|c|c|c|c|c|c|}
\hline & \multicolumn{6}{|c|}{ Dependent Variable: Gini Coefficient in the Early 1990s (Gini) } \\
\hline & (1) & (2) & (3) & (4) & (5) & (6) \\
\hline \multicolumn{7}{|l|}{ Political Dev. } \\
\hline Polity3 & $\begin{array}{l}.85^{* *} \\
(.33)\end{array}$ & & & $\begin{array}{c}.85^{* *} \\
(.35)\end{array}$ & & \\
\hline Demo46 & & $\begin{array}{c}-10.6^{* * * *} \\
(2.5)\end{array}$ & & & $\begin{array}{c}-10.7 * * * \\
(2.6)\end{array}$ & $\begin{array}{c}-6.5 \\
(5.1) \\
\end{array}$ \\
\hline \multicolumn{7}{|l|}{ Globalization } \\
\hline Openness & & & $\begin{array}{l}-.018 \\
(.03) \\
\end{array}$ & $\begin{array}{c}-.01 \\
(.035) \\
\end{array}$ & $\begin{array}{l}-.006 \\
(.04) \\
\end{array}$ & $\begin{array}{l}.015 \\
(.04) \\
\end{array}$ \\
\hline \multicolumn{7}{|l|}{ Interaction } \\
\hline Demo46*Open & & & & & & $\begin{array}{l}-.06 \\
(.06)\end{array}$ \\
\hline Constant & $\begin{array}{c}45.9^{* * *} \\
(2.16)\end{array}$ & $\begin{array}{c}43.5^{* * * *} \\
(1.3)\end{array}$ & $\begin{array}{c}42.4^{* * * *} \\
(2.2)\end{array}$ & $\begin{array}{c}46.8^{* * * *} \\
(2.8)\end{array}$ & $\begin{array}{c}44 * * * \\
(2.2)\end{array}$ & $\begin{array}{c}42.7 * * * \\
(2.6)\end{array}$ \\
\hline Adj. $\mathbf{R}^{2}(\%)$ & 6.8 & 2.1 & -.8 & 5.5 & 19.7 & 19.5 \\
\hline $\mathbf{N}$ & 76 & 67 & 80 & 75 & 66 & 66 \\
\hline
\end{tabular}

Note: See appendix for variable definitions.

$* \quad$ significant at the $90 \%$ level significant at the $95 \%$ level

*** significant at the $99 \%$ level standard error of coefficient in ( )

In contrast to democracy, globalization has no relationship with the demand side of government services both statistically and substantively. It does not seem that globalization increases the demand on government services, aggravating personal income inequality from Column (3). Columns (4) and (5) also illustrate that trade openness does not have a systemic effect on the demand of government services. Meanwhile, two democracy indices do not lose their statistical and substantive significance in the open regression models. Their coefficients have almost the same magnitude and statistical significance as in Columns (1) and (2).

These results contradict previous assumptions that globalization causes income inequality or income volatility and discredit concerns that globalization harmfully affects state autonomy by shifting up the level of demand on government services. ${ }^{9}$ Instead, irrespective of the pressures from globalization, the level

tries in Latin America and Africa show relatively high inequality. Accordingly, intervention of just regional dummy variables (AsiaE, LaAm, SSAfr) improves the explanatory power of the regression model (adjusted R2 $=57 \%$ ) while the fit of democracy disappears. The regressions in Table 2 must be under-specified. Methodological delicacy and extended theoretical consideration should be required. However, in this article I use simpler regression models based on the rationale that mis-specified regression models with more explanatory variables are worse than theory-based simplest models. Causality between inequality and democracy and discussions on other control variables can be referred in Burkhart (1996; 2000).

${ }^{9}$ For a sophisticated study on the effect of globalization on income volatility, refer to Kim (2007). She evidences that there is no causal relations between globalization and income volatility. 
of democracy relieves governments' burden by lowering the level of inequality. Next, Table 3 shows the results of six regressions based on more complicated models than in Table 2. Many of the previous regression analyses about the growth of public expenditure allow us to take advantage of more sophisticated models providing theoretical rationale for controlling socioeconomic and regional variables (refer to Appendix 1).

Table 3. Regression Results: Supply Side

\begin{tabular}{|c|c|c|c|c|c|c|}
\hline & \multicolumn{6}{|c|}{ Dependent Variable: $\mathrm{LnCG}_{9092}$} \\
\hline & (1) & (2) & (3) & (4) & (5) & (6) \\
\hline \multicolumn{7}{|l|}{ Socioecon. } \\
\hline GDPc & $\begin{array}{c}-.000024 \\
(.000016) \\
\end{array}$ & $\begin{array}{c}-.00002 \\
(.000015) \\
\end{array}$ & $\begin{array}{c}-.0002 \\
(.000014) \\
\end{array}$ & $\begin{array}{c}-.000036^{* *} \\
(.00002) \\
\end{array}$ & $\begin{array}{c}-.000037^{* * *} \\
(.00002)\end{array}$ & $\begin{array}{l}-.00004 * * \\
(.00002) \\
\end{array}$ \\
\hline Urban & $\begin{array}{l}.0037 \\
(.0025) \\
\end{array}$ & $\begin{array}{c}.004 \\
(.0025) \\
\end{array}$ & $\begin{array}{l}.0046^{*} \\
(.0024) \\
\end{array}$ & $\begin{array}{l}.0029 \\
(.0026) \\
\end{array}$ & $\begin{array}{c}.003 \\
(.0028) \\
\end{array}$ & $\begin{array}{l}.0027 \\
(.0027) \\
\end{array}$ \\
\hline Depen & $\begin{array}{l}.9 * * \\
(.34) \\
\end{array}$ & $\begin{array}{c}.95 * * * \\
(.34) \\
\end{array}$ & $\begin{array}{c}.96 * * * \\
(.32) \\
\end{array}$ & $\begin{array}{l}.71^{*} \\
(.39) \\
\end{array}$ & $\begin{array}{l}.72^{*} \\
(.39) \\
\end{array}$ & $\begin{array}{l}.73^{*} \\
(.39) \\
\end{array}$ \\
\hline \multicolumn{7}{|l|}{ Region } \\
\hline AsiaE & $\begin{array}{c}-.2 \\
(.14) \\
\end{array}$ & $\begin{array}{l}.23 \\
(.15) \\
\end{array}$ & $\begin{array}{l}.21 \\
(.14) \\
\end{array}$ & $\begin{array}{l}-.3^{*} \\
(.15) \\
\end{array}$ & $\begin{array}{l}-.33^{*} \\
(.16) \\
\end{array}$ & $\begin{array}{c}-.42^{* * *} \\
(.16)\end{array}$ \\
\hline $\mathrm{LaAm}$ & $\begin{array}{l}-.24 * * \\
(.113) \\
\end{array}$ & $\begin{array}{c}-.22 * * \\
(.11) \\
\end{array}$ & $\begin{array}{c}-.21^{* *} \\
(.11) \\
\end{array}$ & $\begin{array}{c}-.25^{* * *} \\
(.11) \\
\end{array}$ & $\begin{array}{c}-.25^{* *} \\
(.12) \\
\end{array}$ & $\begin{array}{c}-.25^{* *} \\
(.11) \\
\end{array}$ \\
\hline SSAfr & $\begin{array}{l}-.016 \\
(.11) \\
\end{array}$ & $\begin{array}{l}-.02 \\
(.12) \\
\end{array}$ & $\begin{array}{l}-.036 \\
(.11) \\
\end{array}$ & $\begin{array}{l}-.013 \\
(.14) \\
\end{array}$ & $\begin{array}{l}-.025 \\
(.14) \\
\end{array}$ & $\begin{array}{l}-.041 \\
(.14) \\
\end{array}$ \\
\hline Soc & $\begin{array}{l}.18 \\
(.13) \\
\end{array}$ & $\begin{array}{l}.19 \\
(.13) \\
\end{array}$ & $\begin{array}{l}.21 * \\
(.12) \\
\end{array}$ & $\begin{array}{c}-.03 \\
(.18) \\
\end{array}$ & $\begin{array}{c}-.03 \\
(.18) \\
\end{array}$ & $\begin{array}{l}-.02 \\
(.18) \\
\end{array}$ \\
\hline \multicolumn{7}{|l|}{ Political Dev. } \\
\hline Polity3 & $\begin{array}{l}.04^{* * * *} \\
(.015) \\
\end{array}$ & $\begin{array}{l}.036^{* *} \\
(.015) \\
\end{array}$ & $\begin{array}{l}.1^{* * *} \\
(.024) \\
\end{array}$ & & & \\
\hline Demo46 & & & & $\begin{array}{l}.34 * * \\
(.14) \\
\end{array}$ & $\begin{array}{l}.34 * * \\
(.14) \\
\end{array}$ & $\begin{array}{l}.7^{* * * *} \\
(.21) \\
\end{array}$ \\
\hline \multicolumn{7}{|l|}{ Globalization } \\
\hline Openness & & $\begin{array}{l}.0018^{*} \\
(.001)\end{array}$ & $\begin{array}{l}.008^{* * *} \\
(.002)\end{array}$ & & $\begin{array}{l}.0006 \\
.001)\end{array}$ & $\begin{array}{l}.0028^{*} \\
(.0015)\end{array}$ \\
\hline \multicolumn{7}{|l|}{ Interaction } \\
\hline Polity3*Open & & & $\begin{array}{c}-.0009^{* * *} \\
(.0002) \\
\end{array}$ & & & \\
\hline Demo46*Open & & & & & & $\begin{array}{c}-.005 * * \\
(.002) \\
\end{array}$ \\
\hline Con & $\begin{array}{c}2.35 * * * \\
(.32)\end{array}$ & $\begin{array}{c}2.25 * * * \\
(.31)\end{array}$ & $\begin{array}{c}2.05 * * * \\
(.32)\end{array}$ & $\begin{array}{c}2.68 * * * \\
(.36)\end{array}$ & $\begin{array}{c}2.66 * * * \\
(.37)\end{array}$ & $\begin{array}{c}2.53 * * * * \\
(.36)\end{array}$ \\
\hline Adj. $R^{2}(\%)$ & 43 & 41.6 & 48.4 & 44.4 & 41.5 & 45.4 \\
\hline $\mathbf{N}$ & 97 & 96 & 96 & 75 & 74 & 74 \\
\hline
\end{tabular}

Note: See appendix for variable definitions.

* $\quad$ significant at the $90 \%$ level $\quad * * \quad$ significant at the $95 \%$ level

*** $\quad$ significant at the $99 \%$ level standard error of coefficient in ( ) 
Regressors explain $43 \%$ and $44 \%$ of the variance of government consumption in Columns (1) and (4), respectively. GDP per capita (GDPc) explains the variance of government consumption at 95\% confidence interval in Column (4). Although the magnitude of the coefficient is not substantively significant, GDPc has a negative relationship with government consumption. These results run counter to Wagner's law that public service is elastic to income because people want a higher level of public service as their income increases.

Following conventional wisdom, dependence ratio (Depen) explains the variance of government activities at .05 level of statistical significance in Column (1). Substantively, 1 unit change of the dependence ratio brings about a marginal increase of $146 \%$ of the previous amount of government consumption, other things being equal. ${ }^{10}$

The primary task in this subsection is to see how democracy influences the supply of government activities. Both Polity3 and Demo46 have positive coefficients, whose magnitude looks almost the same when we take into account their scale, with conventionally accepted statistical significance. Substantively, democracy tends to make the government supply $40 \%$ more than non-democratic government based on Column (4). A one unit increase in the democracy index brings about a $4 \%$ of marginal increase of government supply in Column (1). ${ }^{11}$

A counterfactual situation is helpful to explain how a one unit improvement in democracy affects government consumption based on data from Column (1). Suppose a western European country with mean values for the other control variables except the degree of democracy. Its government may spend $19 \%$ of its GDP on activities. The marginal increase in the supply of government activities would be about $1 \%$ as the country improves the degree of democracy (polity3) by one unit. $^{12}$

Columns (2), (3), (5) and (6) are the results of regression models taking into account globalization effect on the supply of government activities. Columns (2) and (5) show that trade openness does not affect the level of government con-

${ }^{10}$ If we denote the previous level of government consumption and a resulting level with a unit change in dependence ratio as $\mathrm{LnCG}_{p}$ and $\mathrm{LnCG}_{c}$, respectively. $\mathrm{LnCG}_{c}-\mathrm{LnCG}_{p}=\mathrm{Ln}_{\mathrm{C}}\left(\mathrm{CG}_{c} / \mathrm{CG}_{p}\right)=.9$. Accordingly, $\mathrm{CG}_{c} / \mathrm{CG}_{p}=2.46$. Referentially, the value of dependence ratio ranges between .41 and 1.09 in the dataset.

${ }^{11} \mathrm{LnCG}_{c}-\mathrm{LnCGp}=\mathrm{Ln}\left(\mathrm{CG}_{c} / \mathrm{CG}_{p}\right)=.04$, therefore, $\mathrm{CG}_{c} / \mathrm{CG}_{p}=1.04$ in Column (1). LnCG $\mathrm{LnCG}_{p}=\mathrm{Ln}\left(\mathrm{CG}_{c} / \mathrm{CG}_{p}\right)=.34$, therefore, $\mathrm{CG}_{c} / \mathrm{CG}_{p}=1.4$ in Column (4).

12 This counterfactual government consumes 19\% of GDP. Other variable being equal, 1 unit increase of democracy index makes the government spend .76\% of GDP ( $=19 * .04)$. There must be a slight numerical difference because I calculate the marginal change by plugging in the mean values from a larger observation than used in Column (1). 
sumption. In addition, it does not interfere with the effect of the other variables on government activities: their coefficient and statistical significance are almost the same as shown in Columns (1) and (4). Particularly, both democracy variables maintain statistical and substantive meaning despite the intervention of globalization variable. Columns (2) and (5) confirm that globalization does not explain the variation of government consumption. In summary, the regression analyses presented here confirms that Democracy induces the state to supply more public services (H2).

Columns (3) and (6) show the regression outcomes for a model that includes an interaction between democracy and globalization. This interaction term is included to see whether there is any change in the slope term of trade openness in a subset of democratic countries. The results of this regression analysis are theoretically interesting. Columns (3) and (6) explain $48 \%$ and $45 \%$ of the variance of the government consumption, respectively. Meriting particular attention is that the intervention of the interaction term in Columns (3) and (6) nearly doubles the positive influence of democracy on the supply of government consumption. Substantively, democracy on average increases government supply by $100 \%$ compared to non-democratic government based on Column (6). A one unit increase in the variable Polity 3 brings about a 10\% marginal increase in government supply based on Column (3).13

In sharp contrast to the positive effect of democracy on the supply of public services, the coefficients of globalization in Columns (3) and (6) are both statistically and substantively insignificant when the interaction term between democracy and globalization is included. ${ }^{14}$ Alongside Table 2, Table 3 does not confirm Rodrik's "compensation hypothesis." Globalization does not increase the demand and the supply of government services.

Let us turn back to the original question related with the interaction term, whether there is any change in the slope coefficient of trade openness in a subset of democratic countries. Through the Chow test based on Column (6), through this research I find a difference between democratic and non-democratic subsets in terms of slope coefficient of trade openness. In particular, it is worth noting that the slope coefficient of trade openness becomes negative in a subset of democratic countries. How should we interpret this regression outcome? Should we interpret that globalization decreases the supply of government ser-

${ }^{13} \mathrm{LnCG}_{c}-\mathrm{LnCG}_{p}=\mathrm{Ln}\left(\mathrm{CG}_{c} / \mathrm{CG}_{p}\right)=.1$, therefore, $\mathrm{CG}_{c} / \mathrm{CG}_{p}=1.1$ in model (3). $\mathrm{LnCG}_{c}-\mathrm{LnCG}_{p}=\mathrm{Ln}$ $\left(\mathrm{CG}_{c} / \mathrm{CG}_{p}\right)=.7$, therefore, $\mathrm{CG}_{c} / \mathrm{CG}_{p}=2$ in Column (6).

${ }^{14}$ Anti-logged values of the coefficients are almost 1, which means that expected marginal change in level of consumption is zero no matter how much the variables vary. 
vices in democratic countries? That sounds rather far-fetched. Instead, alongside the regression outcomes in Table 2, we can draw an interpretation that democracy lowers the demand of government services even in an era of globalization. To put it another way, even though globalization gives rise to income volatility and thus increases demand for government services ${ }^{15}$, democracy can lower the level of demand for government services (H1).

Yet, there remain additional tests for skeptics who argue that even though democracy increases the supply of government services quantitatively, it cannot guarantee the qualitative healthiness of government activities. For instance, if democracy can increase the level of government consumption, it can also bring about budget deficit and, moreover, chronic inflation.

Table 4. Regression Results: Fiscal and Macroeconomic Healthiness

\begin{tabular}{|c|c|c|c|c|c|c|}
\hline \multirow[t]{2}{*}{ Dependent Variable } & \multicolumn{3}{|c|}{ Defi } & \multicolumn{3}{|c|}{ Infla } \\
\hline & (1) & (2) & (3) & (1) & (2) & (3) \\
\hline \multicolumn{7}{|l|}{ Political Dev. } \\
\hline Polity3 & $\begin{array}{l}.174 \\
(.16) \\
\end{array}$ & $\begin{array}{l}-13 \\
(.16) \\
\end{array}$ & $\begin{array}{l}-.29 \\
. .3) \\
\end{array}$ & $\begin{array}{l}10.45 \\
(15.1) \\
\end{array}$ & $\begin{array}{c}11.6 \\
(15.7) \\
\end{array}$ & $\begin{array}{c}25.9 \\
(28.25) \\
\end{array}$ \\
\hline \multicolumn{7}{|l|}{ Globalization } \\
\hline Openness & & $\begin{array}{c}.018 \\
(.013)\end{array}$ & $\begin{array}{c}.005 \\
(.024)\end{array}$ & & $\begin{array}{c}-1 \\
(1.2)\end{array}$ & $\begin{array}{c}.35 \\
(2.47)\end{array}$ \\
\hline \multicolumn{7}{|l|}{ Interaction } \\
\hline Polity $3 *$ Open & & & $\begin{array}{c}-.002 \\
(.003) \\
\end{array}$ & & & $\begin{array}{l}.2 \\
(.3) \\
\end{array}$ \\
\hline Adj. $\mathbf{R}^{2}(\%)$ & 16.5 & 13.4 & 12.6 & 10.3 & 10 & 9.3 \\
\hline $\mathbf{N}$ & & 81 & 81 & 97 & 97 & 97 \\
\hline
\end{tabular}

O Omission Of Other Control Variables: GDPc, Urban, Depen, AsiaE, LaAm, SSAfr, Soc. Note: See appendix for variable definitions.

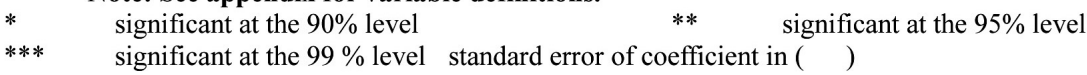

Assuming that government consumption may occur concomitant with fiscal debt and macroeconomic instability, this study regresses budget deficit and inflation rate on the same explanatory variables as in Table 3 . The regression results are summarized in Table 4.

Democracy does not have any systemic relationship with budget deficit and inflation rate. Globalization also does not explain both dependent variables.

${ }^{15}$ At .10 level of statistical significance, trade openness has a positive regression coefficient although its substantive effect on government consumption is weak. 
Although regression results do not confirm the hypotheses of desirable role of democracy $\left(\mathrm{H}_{3}\right)$ and the deleterious role of globalization $\left(\mathrm{H}_{4}\right)$ in government fiscal activities and macroeconomic performance, they also deny the skeptics' argument that democracy can contribute to budget deficit and inflation.

\section{CONCLUSION}

In this article I attempt to illuminate the relationship between globalization and the demand and supply of government activities when domestic institutions are taken into account as an intervening variable. Using a large N-sample to untangle this relationship, this research study finds the following. First, democracy mitigates the degree of inequality and globalization does not aggravate inequality. Second, while globalization does not have a significant relationship with government consumption, democracy has a positive linear relationship with government consumption. Third, globalization and democracy do not determine the level of budget deficits or inflation.

These findings question much of the widely accepted positive correlation between economic openness and public expenditure. If it is assumed that the ultimate constraint on state autonomy occurs when a state fails to supply enough public services to meet public demand, the findings also weaken the claim that globalization constrains state autonomy. Rather, in this article I show that democracy helps the state retain its autonomy whether or not it is being integrated into the world economy. Democratic institutions matter a great deal for state autonomy in an increasingly globalized world.

These findings corroborate the rationale behind institutional approaches that attempt to sort out the relationship between globalization and domestic politics. Theoretically, even if external shocks intensify domestic conflicts around class, social, and cultural cleavages, democracy helps the state manage conflicts and thereby lessen their impact. This conclusion is particularly salient in underdeveloped and developing countries where pressures from without can be exploited to impose greater intervention in the economy and a tightening of civil liberties. To the extent that democratization is equivalent to political development -an arrangement that creates incentives for education, communication, interest articulation and accountability-democratic institutions and the political development they engender provide a fundamental solution to many kinds of conflicts, including conflicts produced by globalization.

While the above findings center around the article's chief empirical goal, another research agenda this research purports to advance is the study of state auton- 
omy from an institutional point of view. Previous research on the impact of globalization on a country's domestic political landscape has examined whether the state has maintained sound macroeconomic performance in the face of external shocks. Yet macroeconomic performance is not always normatively desirable if measured by macroeconomic indicators alone. Often times these overarching measures are used to justify dictatorships in developmental states.

Thus, we need a generalized model for understanding state autonomy that is empirically grounded and normatively desirable. In this article I have attempted to develop a model that serves both purposes by examining the supply and the demand of state's services. Projecting beyond the immediate goals of this study, it is hoped that the attempt to create a normatively and empirically pleasing model will shed light on future forms of state governance.

To advance this study, three directions for further academic inquiry are recommended. First, obtaining a finer grained measure for the effort behind popular demand and state supply of public services would be beneficial. Second, fitting nonlinear models that better capture the effects of globalization would help explain the impact of democracy at intermediary stages of political development. Third, a model that can separate out the independent effects of globalization on democracy and of democracy on globalization would help resolve endogeneity issues (Held 1991; Barber 2000; Ehrlich 2007; Li and Reuveny 2003; Rigobon and Rodrik 2005; Rogowski 1987; Rudra 2005).

On an optimistic parting note, it is plausible that the freer exchange of goods, services and capital has been accompanied by the international transmission of democratic practices and ideals. As these democratic practices and ideals find root in non-democratic contexts throughout the world, it is hoped that they too will act as buffers from the ill-effects of globalization for the populations that can least afford to suffer from these ill-effects. This plausibility can be studied in scientific ways and provide fertile ground to apply various institutional approaches to studying the relationship between globalization and state autonomy.

Finally, let us draw a normative implication for the current events in the European Union mentioned at the beginning of this article. It is striking that those in economic crisis in the region hold common in that they have a shorter history of democracy than the Inner Six. This article sheds light on why not only developing but also advanced industrial countries should keep improving their state governance by reinforcing democratic institutions to survive ever-increasing external shocks in the era of globalization. 


\section{REFERENCES}

Alvarez, Michael, Jose A. Cheibub, Fernando Limongi and Adam Przeworski. 1996. "Classifying Political Regimes." Studies in Comparative International Development 31, 3-36.

Andrews, David. 1994. "Capital Mobility and State Autonomy: Toward a Structural Theory of International Monetary Relations." International Studies Quarterly 38, 193-218.

Bannock, Graham, Ron Baxter and Evan Davis. 1998. Dictionary of Economics. New York: Penguin.

Barber, Benjamin R. 2000. "Challenges to the Common Good in the Age of Globalism.” Social Education 64, 8-13.

Barro, Robert J. 1991. "Economic Growth in a Cross Section of Countries." Quarterly Journal of Economics 106, 407-443.

Burkhart, Ross E. 1996. "Comparative Democracy and Income Distribution: Shape and Direction of the Causal Arrow." Journal of Politics 59, 148-164. . 2000. "Economic Freedom and Democracy: Post-cold War Tests." European Journal of Political Research 37, 237-253.

Cameron, David. 1978. "The Expansion of the Public Economy: A Comparative Analysis." American Political Science Review 72, 1243-1261.

Cerny, Philip. 1994. "The Dynamics of Financial Globalization: Technology, Market Structure, and Policy Response.” Policy Sciences 27(4), 319-342.

Cheibub, Jose Antonio. 1998. "Political Regimes and the Extractive Capacity of Governments: Taxation in Democracy and Dictatorships." World Politics 50(3), 349-376.

Cohen, Benjamin. 1995. "The Triad and the Unholy Trinity: Problems of International Monetary Cooperation.” In Jeffrey Frieden and David Lake eds., International Political Economy, New York: St. Martins Press. 1998. The Geography of Money. Ithaca: Cornell University Press.

Dixit, Avinash. 2003. "Some Lessons from Transaction-Cost Politics for LessDeveloped Countries." Economics \& Politics 14(2), 107-133.

Ehrlich, Sean. 2007. "Access to Protection: Domestic Institutions and Trade Policy in Democracies." International Organization 61(3), 571-605.

Evans, Peter. 1995. Embedded Autonomy: States and Industrial Transformation. Cambridge: Cambridge University Press. . 1997. "The Eclipse of the State?: Reflections on Stateness in an Era of Globalization." World Politics 50(1), 62-87.

Featherstone, Kevin. 2011. "The Greek Sovereign Debt Crisis and EMU: A Failing 
State in Skewed Regime.” Journal of Common Market Studies 49(2), 193-217.

Freedom House. 2004. Freedom in the World: Comparative Rankings, 19762004. Washington D.C.: Freedom House.

Garrett, Geoffrey. 1995. "Capital Mobility, Trade, and the Domestic Politics of Economic Policy.” International Organization 49, 657-687. . 1998a. "Global Markets and National Politics: Collision Course or Virtuous Circle?” International Organization 52, 787-824. . 1998b. Partisan Politics in the Global Economy. Cambridge: Cambridge University Press.

Gilpin, Robert. 2000. The Challenge of Global Capitalism: The World Economy in the 21st Century. Princeton: Princeton University Press.

Gill, Stephen and David Law. 1989. "Global Hegemony and the Structural Power of Capital.” International Studies Quarterly 33, 475-499.

Goodman, John and Louis Pauly. 1993. "The Obsolescence of Capital Controls?: Economic Management in an Age of Global Market." World Politics 32(4), 50-82.

Hall, Peter and David Soskice. 2001. Varieties of Capitalism: The Institutional Foundations of Comparative Advantage. New York: Oxford University Press.

Held, David. 1991. "Democracy, the Nation-state and the Global System." Economy and Society 20, 138-172.

Heller, Peter and Jack Diamond. 1990. "International Comparisons of Government Expenditure Revisited: The Developing Countries, 197586." IMF Occasional Paper 69. Washington D.C.: International Monetary Fund.

Helleiner, Eric. 1994. States and the Reemergence of Global Finance. Ithaca: Cornell University Press.

Hinnfors, Jonas and Jon Pierre. 1998. "The Politics of Currency Crises in Sweden: Policy Choice in a Globalised Economy." West European Politics 21(3), 103-119.

Hirst, Paul and Grahame Thompson. 1999. Globalization in Question: The International Economy and the Possibility of Governance. Malden, MA: Polity Press.

Jaggers, Keith and Ted Gurr. 1995. Polity III: Regime Type and Political Authority, 1800-1994. Ann Arbor: Inter-university Consortium for Political and Social Research (ICPSR 6695).

Keohane, Robert and Helen Milner. eds. 1996. Internationalization and Domestic 
Politics. Cambridge: Cambridge University Press.

Keefer, Philip. 2007. "Elections, Special Interests, and Financial Crisis." International Organization 61(1), 607-641.

Kim, So Young. 2007. "Openness, External Risk, and Volatility: Implications for the Compensation Hypothesis." International Organization 61(1), 181216.

Lehner, Franz and Ulrich Widmaier. 1983. "Market Failure and Growth of Government: A Sociological Explanation.” In Charles Lewis Taylor ed., Why Governments Grow: Measuring Public Sector Size. Beverly Hills, CA: Sage.

Levi, Margaret. 1988. Of Rule and Revenue. Berkeley, CA: University of California Press.

Li, Quan and Rafael Reuveny. 2003. "Economic Globalization and Democracy: An Empirical Analysis." British Journal of Political Science 33(1), 29-54. McKenzie, Richard and Dwight Lee. 1991. Quicksilver Capital: How the Rapid Movement of Wealth Has Changed the World. New York: Free Press.

McLaughlin, Sara, Scott Gates, Havard Hegre, Ranveig Gissinger and Nils Petter Gleditsch. 1998. "Timing the Changes in Political Structure." Journal of Conflict Resolution 42(2): 231-242.

Mishra, Ramesh. 1996. "The Welfare of Nations." In Robert Boyer and Daniel Drache, eds., States Against Markets: The Limit of Globalization. New York: Routledge.

Musgrave, Richard. 1978. The Future of Fiscal Policy: A Reassessment. Leuven: Leuven University Press.

OECD. 1985. "The Role of the Public Sector: Causes and Consequences of the Growth of Government." OECD Economic Studies 4 (Spring).

Önis, Ziya. 1991. "The Logic of the Developmental State." Comparative Politics 24(1), 109-126.

Omae, Kenich. 1995. The End of the Nation State: The Rise of Regional Economies. New York: Free Press.

Rigobon, Roberto and Dani Rodrik. 2005. "Rule of Law, Democracy, Openness, and Income." Economics of Transition 13(3), 533-563.

Rodrik, Dani. 1996. "Why Do More Open Economies Have Bigger Governments?" NBER Working Paper Series 5537.

. 1999. "Participatory Politics, Social Cooperation, and Economic Stability." Mimeo.

Rogowski, Ronald. 1987. "Trade and the Variety of Democratic Institutions." International Organization 41, 203-223.

Rudra, Nita. 2005. "Globalization and Strengthening Democracy in the 
Developing World.” American Journal of Political Science 49(4), 704730.

Schmidt, Manfred. 1983. "The Growth of the Tax State: The Industrial Democracies, 1950-1978." In Charles Lewis Taylor ed., Why Governments Grow: Measuring Public Sector Size. Beverly Hills, CA: Sage.

Sgherri, Silvia and Edda Zoli. 2009. "Euro Area Sovereign Risk During the Crisis." IMF Working Paper No. 09/222.

Sheve, Kenneth and Matthew Slaughter. 2004. "Economic Insecurity and the Globalization of Production." American Journal of Political Science 48(4), 662-674.

Strange, Susan. 1986. Casino Capitalism. Oxford: Blackwell Business.

Tanzi, Vito. 2000. Policies, Institutions and the Dark Side of Economics. Northampton, MA: Edward Elgar.

Tanzi, Vito and Ludger Schuknecht. 1995. "The Growth of Government and the Reform of the State in Industrial Countries." IMF Working Paper 130.

Wade, Robert. 1990. Governing the Market: Economic Theory and the Role of Government in East Asian Industrialization. Princeton: Princeton University Press.

Weiss, Linda. 1995. "Governed interdependence: Rethinking the governmentbusiness relationship in East Asia." The Pacific Review 8(4): 589-616.

Weiss, Linda. 1998. The Myth of the Powerless State: Governing the Economy in a Global Era. Cambridge: Polity Press. 


\section{Appendix 1. Variable Selection}

\section{List of Variables and Sources}

\begin{tabular}{|c|c|c|}
\hline Variable & Definition & Source \\
\hline AsiaE & Dummy for East Asian countries & Barro \& Lee 1944 \\
\hline CG9092 & $\begin{array}{l}\text { Government consumption as a \% of GDP (average } \\
\text { from1990 to 1992) }\end{array}$ & PWT56 \\
\hline Defi & Budget deficit as \% of GDP averaged from 1990 to 1992 & World Data 1995 \\
\hline Demo46 & Dummy for democracy in past 46 years from 1950 to 1995 & $\begin{array}{l}\text { Alvarez et al (1996); Europa } \\
\text { World Yearbook (1998) }\end{array}$ \\
\hline Demo70s & Index of Democracy in 1970s & Freedom House 2004 \\
\hline Depen & Ratio of Non-labor population to working population & World Data 1995 \\
\hline Gini* $^{*}$ & Gini Coefficient in earily 1990 's** & Deininger and Squire dataset \\
\hline GDPc & GDP/capita in 1990 & Barro \& Lee 1994 \\
\hline Infla & Averaged inflation rate from 1990 to 1992 & $\mathrm{IMP}^{*}$ \\
\hline LaAm & Dummy for Latin American countries & Barro \& Lee 1994 \\
\hline Openness & Openness as \% of Trade/GDP averaged from 1980 to 1989 & PWT56 \\
\hline Pol3xxyy & $\begin{array}{l}\text { Subset of Polity3 from 19xx to 19yy (the same way of calcu- } \\
\text { lation) }\end{array}$ & PWT56 \\
\hline Polity3 & $\begin{array}{l}\Sigma\{(\text { democracy index - autocracy index) *years }\} \div \text { total years } \\
\text { included. (Since the end of WWII till 1994). } \\
\text { cf. Such periods as transition, interruption and interregnum } \\
\text { are excluded }\end{array}$ & Polity IIId \\
\hline Soc & Socialist countries & Barro \& Lee 1994 \\
\hline SSAfr & Dummy for Sub-Saharan countries & Barro \& Lee 1994 \\
\hline Urban & $\%$ Urbanization ratio & World Data1995 \\
\hline
\end{tabular}

*Global Development Finance \& World Development Indicators

\section{Theoretical considerations on control variables}

1) GDPc (income level): According to the proposition that as income increase, people spend proportionately more on services, income level is supposed to have positive relation with government consumption. It is called as Wagner's law.

2) Urbanization: Urbanization is assumed to influence the level of government consumption bringing about changes in economic and social organization. For instance, urbanization is accompanied with dissolution of traditional extended family. Therefore informal security provided by traditional family should be substituted by formal state security. As a result, urbanization is supposed to increase the level of government consumption. 
3) Dependence ratio: The higher rate of nonworking population to labor force needs the more public provision.

4) Regional dummies: Regional classification provides social, cultural, and demographical variation in regression analysis on growth models and public expenditure. For example, Sub-Saharan African countries are common in poor human resources due to lower level of secondary education and thereby low level of economic growth. In this situation, there is expected government consumption for public services. Recently, latitude of countries has been used instead of these regional dummies. Regional dummies have various implications depending on contexts.

\section{Made-up data}

Regression analyses make up for the missing data with the most updated year data available in order to prohibit the loss of the number of cases. The cases used are as follows; Luxembourg (1985), Austria (1986), Ireland (1987), Lesotho (1987), Algeria (1988), Greece (1988), Republic of Korea (1988), Argentina (1989), Brazil (1989), Costa Rica (1989), Guatemala (1989), Malaysia (1989), Panama (1989), Puerto Rico (1989), Singapore (1989), Spain (1989).

\section{Gini coefficient}

For understanding the Gini coefficient, we need to have some knowledge of the Lorenz Curve. The Lorenz Curve is a graphical representation showing the degree of inequality of a frequency distribution in which the cumulative percentages of a population (e.g., taxpayers, firms) are plotted against the cumulative percentage of the variable under study (e.g., incomes, employment). A straight line rising at an angle of $45^{\circ}$ from the start on the graph will indicate perfect equality. For example, $10 \%$ of taxpayers contribute $10 \%$ of tax revenue $20 \%$ of taxpayers contribute $20 \%$ of tax revenue. However, a real distribution may well be unequal. When such a distribution is plotted, a curve will be traced below the $45^{\circ}$ line and the degree of curvature will be greater, the greater the inequality (Bannock et al. 1998, 252).

Based on Lorenz Curve, Gini coefficient is measured as:

$\mathrm{G}=$ Area between Lorenz Curve and $45^{\circ}$ line $\div$ Area above the $45^{\circ}$ line Accordingly, the less the Gini coefficient, the less the inequality. When G equals to $\mathrm{o}$, it means prefect equality. 


\section{Appendix 2. Changes in Democracy Index}

\begin{tabular}{|c|c|c|c|}
\hline & Unchanged & Improving & Deteriorating \\
\hline Area & $\begin{array}{l}\text { *Underline indicates } \\
\text { Authoritarian countries. } \\
\text { ** The others are advanced } \\
\text { democracy }\end{array}$ & \multicolumn{2}{|c|}{ Italic Bold indicates socialist countries } \\
\hline AsiaE & $\begin{array}{l}\text { Papua New Guinea } \\
\text { Philippines }\end{array}$ & $\begin{array}{l}\text { Korea, Rep. } \\
\text { Taiwan } \\
\text { Thailand }\end{array}$ & $\begin{array}{l}\text { Fiji } \\
\text { Indonesia } \\
\text { Malaysia } \\
\text { Singapore }\end{array}$ \\
\hline LaAm & $\begin{array}{l}\text { Costa Rica } \\
\text { Jamaica }\end{array}$ & \begin{tabular}{|l} 
Argentina \\
Bolivia \\
Brazil \\
Colombia \\
Dominican Republic \\
Ecuador \\
El Salvador \\
Guatemala \\
Haiti \\
Honduras \\
Mexico \\
Nicaragua \\
Paraguay \\
Peru \\
Trinidad and Tobago \\
Venezuela
\end{tabular} & $\begin{array}{l}\text { Chile } \\
\text { Guyana } \\
\text { Panama } \\
\text { Uruguay }\end{array}$ \\
\hline OECD & $\begin{array}{l}\text { Australia } \\
\text { Austria } \\
\text { Belgium } \\
\text { Canada } \\
\text { Denmark } \\
\text { Finland } \\
\text { Germany } \\
\text { Iceland } \\
\text { Italy } \\
\text { Japan } \\
\text { Luxembourg } \\
\text { Netherlands } \\
\text { New Zealand } \\
\text { Norway } \\
\text { Sweden } \\
\text { Switzerland } \\
\text { United Kingdom } \\
\text { United States }\end{array}$ & \begin{tabular}{|l|} 
France \\
Greece \\
Ireland \\
Portugal \\
Spain
\end{tabular} & Turkey \\
\hline SSAfr & $\begin{array}{l}\text { Botswana } \\
\text { Burundi } \\
\text { Mauritania } \\
\underline{\text { Swaziland }} \\
\end{array}$ & $\begin{array}{l}\text { Angola } \\
\text { Benin } \\
\text { Central African Republic } \\
\text { Chad } \\
\text { Ethiopia } \\
\text { Guinea } \\
\text { Mali } \\
\text { Mauritius }\end{array}$ & $\begin{array}{l}\text { Cameroon } \\
\text { Comoros } \\
\text { Congo, Rep. } \\
\text { Gabon } \\
\text { Gambia, The } \\
\text { Ghana } \\
\text { Guinea-Bissau } \\
\text { Kenya }\end{array}$ \\
\hline
\end{tabular}


Globalization, Democracy and State Autonomy | 189

\begin{tabular}{|c|c|c|c|}
\hline & Unchanged & Improving & Deteriorating \\
\hline SSAfr & & $\begin{array}{l}\text { Mozambique } \\
\text { Niger } \\
\text { South Africa } \\
\text { Tanzania } \\
\text { Uganda }\end{array}$ & $\begin{array}{l}\text { Lesotho } \\
\text { Liberia } \\
\text { Nigeria } \\
\text { Rwanda } \\
\text { Sierra Leone } \\
\text { Somalia } \\
\text { Sudan } \\
\text { Togo } \\
\text { Zambia } \\
\text { Zimbabwe } \\
\end{array}$ \\
\hline Soc & & $\begin{array}{l}\text { China } \\
\text { Hungary } \\
\text { Poland } \\
\text { Yugoslavia, FR }\end{array}$ & $\begin{array}{l}\text { Congo, Rep. } \\
\text { Zimbabwe }\end{array}$ \\
\hline Other & $\begin{array}{l}\text { Arab Rep. } \\
\text { Egypt. } \\
\text { Saudi Arabia } \\
\text { United Arab Emirates } \\
\end{array}$ & \begin{tabular}{|l|} 
Algeria \\
Bahrain \\
Cyprus \\
Jordan \\
Kuwait \\
Morocco \\
Nepal \\
Senegal \\
Tunisia
\end{tabular} & \begin{tabular}{|l} 
India \\
Iraq \\
Israel \\
Myanmar \\
Oman \\
Pakistan \\
Sri Lanka \\
Yemen, Rep.
\end{tabular} \\
\hline
\end{tabular}

